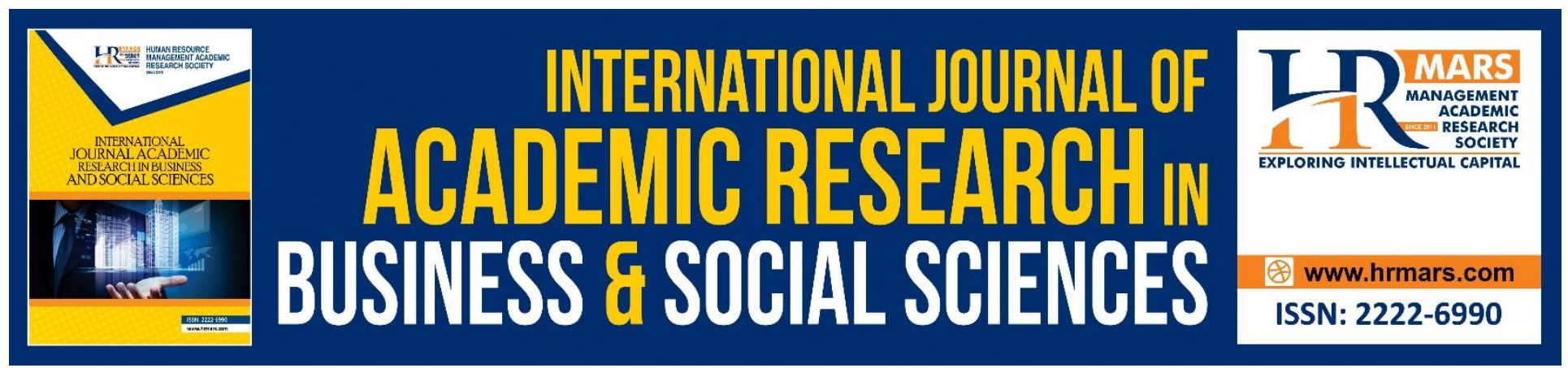

\title{
Protecting the Children's Right to Nationality in Malaysia: An Appraisal
}

\author{
Roslina Che Soh @Yusoff, Nor Hafizah Mohd Badrol Afandi, Noraini Md \\ Hashim, Nora Abdul Hak
}

To Link this Article: http://dx.doi.org/10.6007/IJARBSS/v9-i6/5956

DOI: 10.6007/IJARBSS/v9-i6/5956

Received: 19 April 2019, Revised: 17 May 2019, Accepted: 04 June 2019

Published Online: 30 June 2019

In-Text Citation: (Yusoff, Afandi, Hashim, \& Hak, 2019)

To Cite this Article: Yusoff, R. C. S., Afandi, N. H. M. B., Hashim, N. M., \& Hak, N. A. (2019). Protecting the Children's Right to Nationality in Malaysia: An Appraisal. International Journal of Academic Research Business and Social Sciences, 9(6), 358-368.

\section{Copyright: (C) 2019 The Author(s)}

Published by Human Resource Management Academic Research Society (www.hrmars.com)

This article is published under the Creative Commons Attribution (CC BY 4.0) license. Anyone may reproduce, distribute, translate and create derivative works of this article (for both commercial and non-commercial purposes), subject to full attribution to the original publication and authors. The full terms of this license may be seen

at: http://creativecommons.org/licences/by/4.0/legalcode

Vol. 9, No. 6, 2019, Pg. 358 - 368

http://hrmars.com/index.php/pages/detail/IJARBSS

JOURNAL HOMEPAGE

Full Terms \& Conditions of access and use can be found at http://hrmars.com/index.php/pages/detail/publication-ethics 


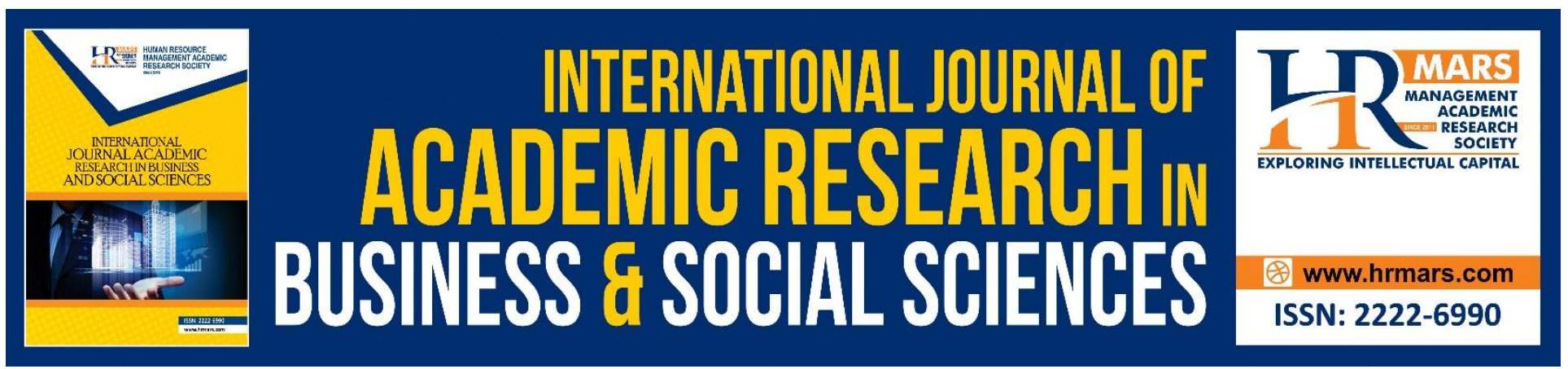

\title{
Protecting the Children's Right to Nationality in Malaysia: An Appraisal
}

\section{Roslina Che Soh @Yusoff, Nor Hafizah Mohd Badrol Afandi, Noraini Md Hashim, Nora Abdul Hak}

Ahmad Ibrahim Kulliyyah of Laws, International Islamic University Malaysia, Jalan Gombak 53100, Kuala Lumpur, Malaysia

\begin{abstract}
Article 7 of the Convention on the Rights of the Child 1989 (CRC) obliges states to realize every child's right to acquire a nationality. Even though most human rights should be enjoyed by all persons, regardless of whether they have a nationality or not, in our modern world, nationality often operates as a legal or practical gateway to the enjoyment of other rights. Where a child lacks a nationality, this creates a situation of severe disadvantage and vulnerability. Statelessness undermines the enjoyment of childhood and the child's opportunity to develop to his or her full potential. Many stateless children are excluded from the benefits of education and are denied equal access to other rights. Such situation is definitely in contravention with the basic principle of best interest of the child as promulgated in Article 3 of the CRC. This paper addresses the extent of the rights of children in Malaysia to acquire nationality particularly in cases involving unregistered birth, illegitimate, foundling or abandoned child and where the immigration status of the parents is uncertain. This paper uses a qualitative data collection method where in-depth document analysis is carried out. Primary sources such as the Acts, Regulations, court orders and decision are scrutinized. On the other hand, secondary sources that are studied include international document reports from relevant websites, law reports, law reviews, legal periodical articles and newspaper reports. The paper is significant as it addresses crucial concerns raised in reference to the current laws relating to the protection of these children in Malaysia. The paper ends with some possible recommendations that may spur improvement to the present legislations towards achieving a sustainable future for the best interest of these children.
\end{abstract}

\section{Introduction}

International law recognizes that each individual has a right to a nationality, and it seeks to protect individuals from the condition of statelessness. Many international human rights instruments include provisions guaranteeing the right to a nationality to all persons and require appropriate states to grant individuals nationality where they would otherwise be stateless. International rules governing 
nationality following state succession strongly affirm the international community's determination that states have an obligation to prevent statelessness. International human rights law provides special protection for a child's right to a nationality, because of the particular vulnerability that children without a nationality endure (Henry, Steiner and Philip Alston, 1996).

The right to a nationality is important because nationality brings individuals under the political and legal protection of the state. National status entitles individuals to the benefits of citizenship and gives them a stake in the governance of their country. Moreover, the right to a nationality is critical to the protection of other fundamental rights. In relation to children, lack of nationality will undermine the enjoyment of childhood and the child's opportunity to develop to his or her full potential. Many stateless children are excluded from the benefits of education and are denied equal access to other rights. Stateless children and their families are often trapped in poverty and grow up knowing only discrimination and marginalization (UNHCR Stateless Report, 2015). UNHCR's estimate, a child is born stateless somewhere in the world every 10 minutes. In 2015 alone, there are at least 10 million people who are stateless with $1 / 3$ of them are children (UNCHR, Statelessness around the World Report, 2015). Stateless happened due to several reasons such as conflicts of nationality laws, war, and breakup of a country, victims of illegal human trafficking and other reasons. The reasons vary from one country to another depending on the social, political and legal structure of a particular country. Statelessness has a detrimental impact on the life of the child, putting him or her at a worrying disadvantage right from the start and affecting the enjoyment of a wide range of other crucial child rights such as birth registration, education and health. Moreover, as long as children continue to be born without a nationality, the problem of statelessness will continue to grow. In many countries, statelessness is inherited from one generation to the next, making it an entrenched and even more challenging problem to address (Institute on Statelessness and Inclusion, 2017).

\section{Methodology}

Research Subject: This paper uses a qualitative data collection method where in-depth document analysis is carried out. Primary sources such as the Acts, Regulations, court orders and decision are scrutinised. On the other hand, secondary sources that are studied include international document reports from relevant websites, law reports, law reviews, legal periodical articles and newspaper reports.

\section{Discussion}

\section{The Right of Every Child to a Nationality under International Law}

The right of every child to acquire a nationality is protected under the Convention on the Rights of the Child 1989 (CRC) and numerous other key human rights conventions. In the CRC, article 7 provides that:

i- The child shall be registered immediately after birth and shall have the right from birth to a name, the right to acquire a nationality and, as far as possible, the right to know and be cared for by his or her parents. 
INTERNATIONAL JOURNAL OF ACADEMIC RESEARCH IN BUSINESS AND SOCIAL SCIENCES Vol. 9, No. 6, June, 2019, E-ISSN: 2222-6990 @ 2019 HRMARS

ii- States Parties shall ensure the implementation of these rights in accordance with their national law and their obligations under the relevant international instruments in this field, in particular where the child would otherwise be stateless.

Under the the 1954 Convention Relating to the Status of Stateless Person, stateless person is defined as a person who is not considered as national by any State under the operation of its laws. Persons who have legitimate claims to citizenship, but who cannot prove their citizenship (e.g., through official identity documentation such as birth records), or whose governments refuse to give effect to their nationality, are also considered to be stateless. Children who are not registered at birth and who remain undocumented are generally not recognized as formal citizens of a nation and are typically described as stateless (Convention Relating to the Status of Stateless Persons, 2014).

Article 8 of the CRC further protects the right of children to preserve their identity, including nationality. The central or guiding principles contained in the CRC are also instrumental in interpreting and protecting children's right to a nationality, to better understand what is demanded of states. These four central principles are: the right to life, survival and development (Article 6), best interests of the child (Article 3), respect for the views of the child (Article 12) and non-discrimination (Article 2). Statelessness can impede a child's development and even survival by obstructing access to healthcare, for instance. Given this and the need to give primary consideration to what is in the best interests of the child whenever any decision or action is taken which involves a child, children should not be left stateless for a long period after birth but must acquire a nationality at birth or as soon as possible after birth (UN High Commissioner for Refugees (UNHCR), 2012). Where children's nationality may be affected by the actions of their parents or of the state, for instance in the case of renunciation or loss of nationality during childhood, there should be space as appropriate for the child's opinion to be considered. The principle of non-discrimination implies, for instance, that regulations aimed at preventing statelessness may not discriminate between children on the basis of their or their parents'status. Supplementing this latter norm are numerous other human rights provisions, which explicitly outlaw discrimination in the enjoyment of the right to a nationality. These include article 5 of the Convention on the Elimination of All Forms of Racial Discrimination (CERD) which prohibits racial or ethnic discrimination in nationality rights; and article 9 of the Convention on the Elimination of All Forms of Discrimination Against Women (CEDAW) which prescribes equal nationality rights for men and women, including with respect to the transmission of nationality to their children (European Network on Statelessness, 2015). The right to a nationality is further laid down in the Universal Declaration of Human Rights (Article 15), the International Covenant on Civil and Political Rights (ICCPR) (Article 24(3)), the Convention on the Rights of Persons with Disabilities (Article 18) and the European Convention on Nationality (ECN) (Article 4(a)). The ways in which states should make sure that every person can obtain a nationality are laid down in the 1961 Convention on the Reduction of Statelessness.

\section{Rights of the States in Granting Nationality}

Despite the fact that right to nationality is considered as a human right and is widely guaranteed by numerous international regulations and declarations, it is important to note that matters of 
nationality fall within the domestic spheres of States (Granczer, 2014). This clearly manifests that the States have exclusive jurisdiction in determining who can obtain nationality and the process of acquiring it. Nevertheless, in exercising this right, the States are guided by the international standards particularly as provided in the 1961 Convention on the Reduction of Statelessness. Article 1 of the 1961 Convention obliges States to grant their nationality to a person born on their territory who would otherwise be stateless. Usually, when a child is born, he or she receives nationality either based on the place of birth (referred to as 'jus soli') or on the nationality of the parents (nationality by descent or 'jus sanguinis') or on a combination of the two. A state can choose to automatically grant nationality at birth or to make a system in which nationality can be acquired following an application procedure. States may also use a combination of these options (European Network on Statelessness, 2014). Many states adopted the combination of the two principles. As far as Malaysia is concern, the right to acquire nationality is duly guaranteed under the Federal Constitution and it also adopted a similar approach of granting nationality (Nor, 2013).

\section{Issues of Nationality of Children in Malaysia}

As being discussed above, lack of nationality will lead to statelessness and the impact is arduous particularly on children, as it will jeopardize their future life and upbringing. The issue of statelessness has always becomes a polemic among all nations worldwide including Malaysia. According to a parliamentary written reply by the Home Minister, Ahmad Zahid Hamidi, there were 15,394 children born in Malaysia who were denied citizenship even though their fathers are Malaysian citizens. This means that every day, there are 8 children born without citizenship. In November last year, the Home Minister revealed that there were 290,437 stateless children in Malaysia who are below the age of 18 (Ching, Malaysiankini, 2017).

Despite the fact that Malaysia is not a signatory to the UN Convention relating to statelessness, it has however adopted the Convention on the Rights of the Child-albeit with some reservations- to Article 7 of the CRC, which specifies the country's obligation in legally recognizing undocumented children. The Federal Constitution generally guarantees the right to acquire citizenship and it may be granted through operation of law, registration naturalization and incorporation of territory. As for those who acquired citizenship through operation of law it refers to persons born before Malaysia Day (16th September 1963), persons born after Malaysia Day as well as those who were born outside the Federation where the fathers of such persons must be citizens and must satisfy one of the requirements, namely, born in the Federation, was in the service of the Federal or State Government, or the birth was registered at the Consulate. In addition, person who is born within the Federation and who is not born a citizen of any country could also acquire citizenship through operation of law (Article 14, Second Schedule Pt 1, II). Citizenship by registration on the otherhand refers to persons who are likely to become citizens through registration, such as foreign-born wives and children of citizens (Article 15 -18). It is essential to note that foreign-born husbands do not come under this category.

Besides the two methods mentioned above citizenship could also be acquired through naturalization under article 19 (1) of the Federal Constitution. The difference between citizenship 
through registration and citizenship through naturalization is that the former requires that the applicant resides in the country for an aggregate of at least five out of seven years prior to the application while the latter requires the applicant to reside in the country for the period of ten years prior to the application.

\section{Factors of Stateless Children in Malaysia}

There are various factors contributing to the problem of statelessness among children in Malaysia. The most common are failure to register marriages and birth of children, abandoned children or foundling, adopted children, children of refugees and undocumented migrants.

\section{i- $\quad$ Failure of marriage registration}

According to Malaysian law, only legally married parents can be listed as spouses on their child's birth certificate. This condition is in turn, becomes the only way to prove the father's identity and for the child to receive Malaysian citizenship. Legal and valid marriage certificate is the deciding factor on whether a child is entitled to Malaysian citizenship. If there is no legal marriage certificate, then the Malaysian government considers the child to be the same nationality as the mother. Section 17 of Part III of Second Schedule of the Federal Constitution, states that illegitimate child would follow the mother's nationality. However this does not solve the problem as the foreign mother has to register her child at her country's embassy or consulate to confirm its nationality or the child will be at risk of becoming stateless. Problem arose if a couple divorces and the child's foreign mother return to her country of origin. In such case, the child's parentage cannot be proven without a valid marriage certificate, thus, leaving the child to be unable to live with the mother or to be granted Malaysian citizenship. The plight of becoming an illegitimate child can be seen in the case of Lim Juen Sian v. Pengarah Pendaftaran Negara (unreported). In this case a child was born out of wedlock in 2010 in Kuala Lumpur to the Malaysian father and a Thai mother. He was denied Malaysian citizenship because the child acquired Thai citizenship under Thai law. (The law accords Thai nationality if the mother or father is a Thai national-even if born outside Thailand). In this case application for the child to be declared as a Malaysian citizen was dismissed because the High court concluded that the child would not be made stateless.

Upon appeal to the Court of Appeal the court ruled that the identity and citizenship status of the parents are unknown. The Court of Appeal went on to say that since the father could not prove that the child was stateless, as required by law, the child could not be shown to be stateless. The court ruled that the identity and citizenship status of the parents are unknown. As the mother is a Thai national therefore the child has its mother citizenship.

\section{ii- $\quad$ Unregistered birth}

Under the Births and Death Registration Act 1957 a child is to be registered regardless whether legitimate, illegitimate or unknown status. The Act applies to all children born in Malaysia whether the child is born alive or not (still birth) (Section 2). The law requires that either the father or the mother of the child to give information on the particulars of the birth. In the absence of both, the requirement to give such information lies on the occupier of the house who has knowledge of the birth of the child or any persons present at birth or any person having charge of the child is qualified 
to give information (Section 7(2)). In practice, a child's birth should be registered within 14 days after his birth. In the event delayed registration the time stipulated is within 15 to 42 days of the child's birth and after 43 days it would be considered as late registration of birth (Ida Lim, 2017). Problem arose when their parents'marriage was not registered. This will lead to a vicious cycle whereby upon non-registration of marriage a child's birth could not be registered. As such they lack identity and became stateless.

Though there are numerous reasons for statelessness, most people without citizenship in Malaysia fall under the category of those who failed to register their birth under the Malaysia law. The effect of non-registration of birth leads to a person being stateless. This is a matter that should be look urgently by the government since the number of late registration of birth in Malaysia is very alarming. Until and unless their births are registered, they are living in limbo and are categorized as stateless children. It is to be clearly emphasized here that birth certificate is the proof of citizenship in Malaysia. Failure to produce a birth certificate could deny a person's claim to being a citizen of the country through operation of law. This was clearly highlighted by the court in deciding the case of Ong Boon Hua @ Chin Peng \& Anor v. Menteri Hal Ehwal Dalam Negeri, Malaysia [2008] 3 ML 625. It was agreed by the judge that the onus is on the appellant to prove that he is a Malaysian citizen by producing his birth certificate.

\section{iii- $\quad$ Adopted children}

In Malaysia, there exist two parallel systems governing adoption of Muslim and non-Muslim children. The non-Muslim children are governed by the civil statute, i.e. the Adoption Act 1952 while the Muslims are governed by the Registration of Adoptions Act 1952 and Syariah laws. In discussing the issue of citizenship among adopted children the Adoption Act 1952 does not address the citizenship of adopted children. The Adoption Act 1952 is not competent as a legal instrument to confer citizenship status to an adopted child under Article 14(1)(b) read with section (1) (a), Part II, Schedule of Federal Constitution. As a result the nationality of adopted children in Malaysia has been determined by the National Registration Department (NRD) in the exercise of its administrative function of registering orders granted by the Malaysian courts. By refusing citizenship to many adopted children, the NRD had forced aggrieved parents to subsequently apply to the Minister of Home Affairs for citizenship for their adopted child which is the sole discretion of the Minister and beyond judicial review. The plight of adopted parents in struggling for their adopted child's citizenship can be seen in an unreported case of Lee Chin Pon \& Anor v. Registrar-General of Births and Deaths, Malaysia (2010) (unreported) where in this case a stateless child who was born in Malaysia and adopted by a Malaysian married couple. The High Court judge in this case allowed the adoptive parents application for judicial review which challenged the NRD's decision in registering their child as a permanent resident in his birth certificate. The court granted inter alia, the declaration for their child's Malaysian citizenship by operation of law under Article 14(1) (b) \&Part II Second Schedule of the Federal Constitution.

Indeed the decision in Lee Chin Pon is a step towards protecting the best interest of adopted children. This case developed the principle that a lawfully adopted child born in Malaysia on or after 
Malaysia Day has the constitutional rights to be recognized as a citizen, provided either of the adoptive parents is a citizen or permanent citizen of Malaysia. The Court of Appeal however in its recent judgement had set aside the High Court's decision in Pang Wee See v. Pendaftar Besar Kelahiran Dan Kematian, Malaysia [2016] 6 MLJ 396. In this case, the judges unanimously were of the view that an Adoption Order issued under the Adoption Act 1952 does not confer Malaysian citizenship to an adopted child although one of his adoptive parents is a Malaysian citizen or a person permanently resident in Malaysia by operation of law, within the contemplation and ambit of Article 14(b) read with section (1) (a) Part II, Second Schedule of the Federal Constitution. To be a Malaysian citizen under this Article, the person must be born in Malaysia and one of his biological parents is at the time of his birth, either a Malaysian citizen or a person who is permanently resident in Malaysia. The applicants in this case did not fulfil the crucial biological, or the jus sanguinis criterion as envisaged under the Article.

\section{iv- $\quad$ Abandoned Children or Foundling}

Abandoned children refers to situations in which a child, usually a baby, is abandoned by a parent or caregiver with the obvious intention of creating permanent separation and situations where a parent places a child in a residential institution without the intention of relinquishing the child permanently (Azizah Mohd, 2007). For citizenship of the abandoned children, Section 19B Second Schedule of the Federal Constitution provides that, for the purpose of Part 1 and Part II of this Schedule, any new born child found exposed in any place shall be presumed, until contrary is shown, to have been born there of a mother permanently resident there, and if he is treated by virtue of this section as born, the date of the finding shall be taken to be the date of the birth\|. Therefore it is proven that abandoned child could acquire citizenship through operation of law under Article 14(1) (b) and (e). However it is important to emphasize that the status of a newborn foundling is not automatically written in his birth certificate as a citizen, but his status of citizenship is stated as 'not yet determined'. This is due to the process of investigation of the status of his parent's citizenship.

\section{$v$ - $\quad$ Children of Refugees and Undocumented Migrants}

The Malaysia's position concerning refugee is that it is not a signatory to the 1954 Convention relating to the Status of Stateless Person. Therefore, the Immigration Act 1959/63 makes no distinction between asylum seekers, refugees, irregular immigrants and undocumented or stateless people. Instead, the groups above are collectively considered undocumented migrants, and both parents and children are facing the threat of arrest. While the state does not grant refugee status or asylum, it has cooperated with UNHCR and generally does not impede other humanitarian organizations from assisting refugees (Kaur, 2007). In 2014, the United Nations High Commissioner for Refugees (UNHCR) estimates there are about 12 million of stateless persons around the globe, with as many as 125,375 in Malaysia of which 40 per cent are children. In Malaysia, most refugees are Rohingyas from Myanmar, while a minority, are from Sri Lanka, Somalia, Iraq, Pakistan, Iran and Afghanistan (Subramaniam, 2014). Some of the refugees or migrants do not possess identification documents and since they live under fear of arrest or harassment from the authorities, they do not register their children born in Malaysia. This means both parents and child are at risk of becoming stateless. In the East Malaysia, there is a large population of stateless children born to Indonesian and Filipino 
INTERNATIONAL JOURNAL OF ACADEMIC RESEARCH IN BUSINESS AND SOCIAL SCIENCES Vol. 9, No. 6, June, 2019, E-ISSN: 2222-6990 @ 2019 HRMARS

immigrants. Even though, some of these children were born in Malaysia, the law does not automatically granted citizenship due to the fact that their parents either stateless or have been repatriated to their own countries.

\section{Conclusion \& Recommendation}

Nationality is an important aspect of a child's identity and serves as a 'gateway' right, facilitating children's access to and enjoyment of their other human rights. Statelessness is never in a child's best interests and international law protects the right of every child to acquire a nationality. Stateless children, though no fault of their own inherit circumstances that limit their potential. When they are denied their right to citizenship or nationality they are vulnerable to various kinds of discrimination, abuse, exploitation and human trafficking. Despite the fact that Malaysia is not a signatory to the UN Convention relating to statelessness, it has however adopted the Convention on the Rights of the Child-albeit with some reservations-which gives all children the right to legal identity. In this regards an effective laws on nationality and universal birth registration are the first steps towards resolving the problem. Though the Federal Constitution provides significant safeguards against statelessness it lacks on the position of foundlings who do not acquire nationality automatically. One has to know that the decisions on citizenship ultimately rest on the Home Minister.

Stateless children also do not have access to formal education, as government schools do not generally accept non-Malaysian or undocumented children. Even they are taken in by the school; they cannot enjoy the free education like other Malaysian children and are not entitled to Textbook Loan Scheme. Only a few have the opportunity to further their studies in public universities, as they need to pay foreign student rates and cannot apply for PTPTN. As a result they have to resort to the informal service centres, which could only provide a very basic education to the children. The Ministry of Education had taken a pro-active move in tackling this issue by sending a circular to all state education departments since March 2009 for the purpose of registering these children in government or government aided school. However in reality it is questionable whether the state education department abides with such circular, looking into the huge number of unregistered birth in Malaysia. In addition, since children without documentation are considered as stateless, thus the government imposes full medical charges on them. They will also be denied of passport and driving license. Facing all these challengers, these children will have great difficulties to excel in life and also having problem to secure a decent job.

One of the ways to counter the issues of stateless children is through the DNA test report. The Deputy Home Minister Datuk Wan Junaidi Tuanku Jaafar said that the DNA analysis reports for stateless children can only be used as a supporting document to apply for Malaysian citizenship but not a mandatory document for approval. However, the government will not grant automatic citizenship to the children born in Malaysia if the parents' marriage are not registered under Malaysian laws and, most importantly, if the mother of the child is not a Malaysian citizen (Jaafar, 2014).

In relation to stateless children who are lawfully adopted, the National Registry Department (NRD) should recognize them as citizens provided that it is proven that they were born in Malaysia and that there is no evidence that they in fact obtained foreign citizenship within a year after their birth in Malaysia. The NRD should also prepare sworn statements and other evidence from the child 
and the relatives on the child's birth in Malaysia to prove such claim. Until such time that the legislature enacts specific legislation to provide for the inclusion of adopted children as citizens, it is hoped that this issue will be tackled by the government and the role played by the courts in defending the rights of the children in this country. In addition, the problem of stateless children in Malaysia may also be resolved by the government by applying Article 15A of the Federal Constitution. This is a way forward in protecting the children's right to nationality. Under this Article the Federal Government may in special circumstances as it thinks fit cause any person under the age of 21 years old to be registered as citizen (Lim, 2017). Since conferment of nationality or citizenship is the discretionary power of the executive, it needs strong political will of the government in resolving the issue of stateless children in this country. This is important towards achieving a sustainable future for the best interest of the child.

\section{Corresponding Author}

Roslina Che Soh@Yusoff, Ahmad Ibrahim Kulliyyah of Laws, International Islamic University Malaysia, Jalan Gombak 53100 Kuala Lumpur, Malaysia, Email: roslinac@iium.edu.my

\section{References}

Kaur, A. (2007). 'Refugees and Refugee Policy in Malaysia' UNEAC Asia Papers (Special Issue Refugees and Refugee Policies in the Asia Pacific

Region)77\&79, http://www.une.edu.au/asiacentre/PDF/No18.pdf (Accessed on 21 September 2017).

Mohd, A. (2007). Protection And Adoption of Abandoned Children in Malaysia, A Comparative Overview with Islamic Law, ILBS, Petaling Jaya Selangor, 23.

Children's Right to Nationality, Institute on Statelessness and Inclusion, (2017). http://www.institutesi.org/ourwork/children.php. (Accessed on 21 September 2017).

Convention Relating to the Status of Stateless Persons, (2014). http://www.unhcr.org/ibelong/wpcontent/uploads/1954-Convention-relating-to-the-Status-of-Stateless-Persons_ENG.pdf. (Accessed on 20 September 2017).

Jaafar, W. J. T. (2014). DNA Findings can Support Application for Citizenship, the Star Online. http://www.thestar.com.my/news/nation/2014/10/14/wan-junaidi-dna-citizenship/. (Accessed on 20 September 2017).

Granczer, M. (2014). The Right to Nationality as a Human Right Hungarian,Y.B.Int'IL.\&Eur.L.15. http://heinonline.org/HOL/LandingPage?handle=hein.journals/huyiel2014\&div=7\&id=\&pag e=. . (Accessed on 20 September 2017).

Steiner, H. J. and Alston P. (1996). International Human Rights In Context: Law, Politics, Morals. Oxford University Press, Great Clarendon Street Oxford, p. 41.

I am Here, I Belong: Urgent Need to End Childhood Statelessness, UNHCR Stateless Report (October 2015).http://www.unchr.org/ibelong/cmsweb/upl/entities/story/Stateless Report_eng_final3.pdf. (Accessed on 20 September 2017).

Lim, Ida. (2017). What lies ahead for a stateless child in Malaysia? Malay Mail Online, http:///sg.news.yahoo.com./lies=ahead stateless child malaysia-225800024.html. (Accessed on 20 September 2017). 
INTERNATIONAL JOURNAL OF ACADEMIC RESEARCH IN BUSINESS AND SOCIAL SCIENCES

Vol. 9, No. 6, June, 2019, E-ISSN: 2222-6990 (C) 2019 HRMARS

No Child Should be Stateless, European Network on Statelessness. (2015).

http://www.statelessness.eu/resources/no-child-should-be-stateless. (Accessed on 20 September 2017).

Afandi, N. H. B. M. B. (2012). Living In Limbo: Constitutional and Legal Issues of Unregistered Birth, Constitutional Law and Human Rights in Malaysia, Sweet \& Maxwell, p. 227.

Subramaniam, P. (2014). Born into the shadows: Malaysia's stateless children. http://www.themalaymailonline.com/malaysia/article/born-into-the-shadows-malaysiasstateless children\#QX9icOhCoSeFDoXI.99. (Accessed on 20 September 2017).

Preventing Childhood Statelessness in Europe: Issues, Gap \& Good Practices, EuropeanNetwork on Statelessness, (2014). Retrieved from http://www. statelessness.eu/resources/preventingchildhood-statelessness-europe-issues-gaps-and good practices. (Accessed on 20 September 2017).

Ching, T. N. (2017). Simplify process of granting citizenship to stateless children. Retrieved from https://www.malaysiakini.com/news/385006\#0S5iS1aSILHIk5k7.99. (Accessed on 20 September 2017).

UN High Commissioner for Refugees (UNHCR), Guidelines on Statelessness No. 4: Ensuring Every Child's Right to Acquire a Nationality through Articles 1-4 of the 1961 Convention on the Reduction of Statelessness, HCR/GS/12/04, Para. 11. (2012). http://www.refworld.org/docid/50d460c72.html. (Accessed on 20 September 2017).

UNCHR, Statelessness around the World (2015). http://www.unhcr.org/statelessness around the world.html. (Accessed on 20 September 2017).

UNHCR, A Special Report: Ending Statelessness Within 10 Years, (2014). http://ibelong.unhcr.org/cmsweb/upl/entities/story/Statelessness/. Accessed on 20 September 2017). 